\title{
FOSL1 wt Allele
}

National Cancer Institute

\section{Source}

National Cancer Institute. FOSL1 wt Allele. NCI Thesaurus. Code C52894.

Human FOSL1 wild-type allele is located in the vicinity of $11 \mathrm{q} 13$ and is approximately $8 \mathrm{~kb}$ in length. This allele, which encodes FOSL1 protein, is involved in transcriptional regulation. 